\title{
Who supports the ECB? Evidence from Eurobarometer survey data
}

Article

Accepted Version

Farvaque, E., Hayat, M. A. and Mihailov, A. (2017) Who supports the ECB? Evidence from Eurobarometer survey data. The World Economy, 40 (4). pp. 654-677. ISSN 1467-9701 doi: https://doi.org/10.1111/twec.12472 Available at https://centaur.reading.ac.uk/66726/

It is advisable to refer to the publisher's version if you intend to cite from the work. See Guidance on citing.

To link to this article DOI: http://dx.doi.org/10.1111/twec.12472

Publisher: Wiley

All outputs in CentAUR are protected by Intellectual Property Rights law, including copyright law. Copyright and IPR is retained by the creators or other copyright holders. Terms and conditions for use of this material are defined in the End User Agreement.

\section{www.reading.ac.uk/centaur}

\section{CentAUR}

Central Archive at the University of Reading

Reading's research outputs online 
PREPRINT version

"Who Supports the ECB? Evidence from Eurobarometer Survey Data"

Forthcoming in The World Economy

Etienne Farvaque, Muhammad Azmat Hayat and Alexander Mihailov

Final (revised and resubmitted) version of 11 July 2016 accepted on 11 September 2016 


\title{
Who Supports the ECB? \\ Evidence from Eurobarometer Survey Data
}

\author{
Etienne Farvaque, ${ }^{1}$ Muhammad Azmat Hayat ${ }^{2}$ and Alexander Mihailov ${ }^{3}$
}

The World Economy, $2^{\text {nd }}$ revision: July 2016

\begin{abstract}
This paper studies the determinants of the support for the European Central Bank (ECB) in the member-countries of the European Monetary Union (EMU) and their evolution from 1999 to 2015. Our contribution is to examine micro-level socio-demographic characteristics from the Eurobarometer surveys jointly with macroeconomic indicators of trust in a central bank in order to evaluate econometrically their relative importance over time. Pseudo-panel logit estimates reveal that the former have a dynamically stable, and generally stronger influence taken altogether, when compared with the latter. Interestingly, we find that while expected inflation becomes a positive determinant of trust in the ECB after the Global Financial Crisis (GFC), actual inflation gets no statistical significance. Having taken centre stage in the monetary policy debate in the Euro area post-GFC and especially since 2013, excessive disinflation and risk of deflation attracted strong attention by the public, and have consequently affected its perceptions about the ECB. Accordingly, our results emphasize forward-lookingness of the EMU population with regard to 'deflation scares' in determining trust in the ECB, in addition to disentangling the contributions of the key individual-level socio-demographic factors, and can duly inform ECB's communication strategy.
\end{abstract}

Keywords: central bank trust, inflation/deflation perceptions, Eurobarometer survey, Global Financial Crisis, European Central Bank, communication strategy

JEL codes: C23, E58, F33, H11, Z13

\footnotetext{
${ }^{1}$ LEM - CNRS (UMR 9221), Université de Lille, Cité Scientifique (SH2), Villeneuve d'Ascq 59655 Cedex, France; Skema Business School, Lille, France; CIRANO, Québec, Canada: etienne.farvaque@univ-lille1.fr

2 Department of Economics, University of the Punjab, Quaid-i-Azam Campus, Lahore, Pakistan: azmathayat.eco@pu.edu.pk

${ }^{3}$ Department of Economics, University of Reading, Whiteknights, Reading RG6 6AA, United Kingdom: a.mihailov@ reading.ac.uk
}

Acknowledgements: We acknowledge particularly stimulating comments from Riccardo Rovelli, as well as from the associate editor and the referees of the journal. We also thank Gunther Capelle-Blancard, Jézabel Couppey-Soubeyran, Hakim Hammadou, Jérôme Héricourt, Julien Idier, Clemens Kool, Bertrand Maillet, Mathias Morys, Manfred Neumann, Kerry Patterson, Agnès Bénassy-Quéré, Koen Schoors, Pierre Siklos, Karsten Staehr, Stéphane Vigeant and the audiences at the joint University of Paris 1 (Panthéon Sorbonne) \& Banque de France workshop in monetary theory, at the annual conferences of the Irish Economic Association in Limerick, the Eurasia Business and Economics Society in Istanbul, and the GdRE/CNRS in Money, Banking and Finance in Reading, as well as at the Russian Summer School on Institutional Economics in Moscow and the Europsymposium conference in Bayreuth. Farvaque has benefited from the financial support of the ANR-JSPS Chorus program. Hayat thanks the Higher Education Commission (HEC) of Pakistan for their financial support. Mihailov is grateful to the University of Lille 1 for granting him an invited professorship that facilitated the work along the project. The usual disclaimer for any remaining errors and omissions applies. 


\section{Introduction}

The Global Financial Crisis (GFC) of 2008-2009 and the subsequent Euro-area debt problems, especially in the so-termed 'peripheral' or PIIGS countries (Portugal, Ireland, Italy, Greece and Spain), have led to doubts and disapproval from politicians and the public with regard to the models, forecasts, policies and communication strategies employed by monetary authorities. This lower credibility of monetary policy increases the incentives of politicians to criticise central banks and to exert pressures on their institutional independence (Waller, 1991). Moreover, since early 2013 excessive disinflation and risk of deflation have taken centre stage in the monetary policy debate in the Euro area, attracting condensed attention by the public. Such turbulent and unusual developments at the background of the Great Moderation (from around 1993 through 2007) have undoubtedly affected the perceptions of the population in the member-states of the European Monetary Union (EMU) about their supranational and highly independent central bank, the European Central Bank (ECB). During such precarious episodes, central banks need the strongest support from the population they can mobilise. Public support is particularly relevant and pressing for a relatively young institution such as the ECB, the more so in the wake of the deepest global recession for nearly a century. Since its creation, the ECB has suffered from accusations of a lack of accountability $^{1}$ and, consequently, of misaligned interests and policies with respect to national governments and electorates. The GFC and the Euro-area debt crisis have made the concern even more acute.

In a nutshell, if people trust the ECB, then its legitimacy as a supranational institution and the credibility of its monetary policy will be higher. ${ }^{2}$ It can furthermore be argued that trust in the ECB and support for its policy could be enhanced by active communication (explaining its objectives, constraints, instruments and effects) with the European polities. A clear and transparent communication strategy is even more needed if the population's support for a central bank's policy declines, as it seems to be the case post-GFC, and not just in the Euro area. But, as Blinder et al. (2008) show, no consensus has shaped out on an optimal communication strategy of a central bank.

\footnotetext{
${ }^{1}$ See, among others, Berman and McNamara (1999), the debate between Buiter (1999) and Issing (1999), and Kaltenthaller et al. (2010).

${ }^{2}$ One can expect central bank support to be also sensitive to the business cycle (Stevenson and Wolfers, 2011).
} 
Although some papers have attempted to check how ECB's communication is received by the markets, very few have been able to ascertain the width of the support for the ECB in the European population at large. It can certainly be affirmed that monetary policy impacts everyone's everyday life. Starting from such a premise, the study of attitudes and values is now recognised as an important source of information for economists, and the availability of the Eurobarometer survey data has put the European integration process under the magnifying glass (see, e.g., Gabel, 1998, or Nelsen and Guth, 2000). Concerning monetary issues in particular, Gärtner (1997), Hayo (1999) and Jonung (2004) examine the emergence of the Euro as a currency and its popular support.

But the trust of the Europeans in the ECB and its evolution over time has not yet been exhaustively explored. In fact, such a literature is only emerging. Moreover, research has mostly looked one-sidedly either at the typical macroeconomic (country-level) indicators determining trust in a central bank, such as inflation, unemployment, real GDP growth and fiscal measures, or at the standard socio-demographic (individual-level) determinants of central bank trust. By contrast, the present paper is among the first to examine micro-level socio-demographic factors from the Eurobarometer surveys jointly with alternative macroeconomic indicators of trust in the ECB over the whole span of the EMU across time (survey waves) and space (member-countries). Our purpose with such an approach is to evaluate and compare the relative importance of these two major types of determinants of trust in the ECB, as well as to study their evolution as the EMU membership has been expanding.

Kaltenthaler and Anderson (2001) analyse the support for a European monetary policy, but in a very early and short sample, 1994-1997, i.e., when the single currency was not yet born. Hudson (2006) provides some evidence on trust in the ECB, showing that the usual sociodemographic variables are significant. However, the data used is for the year 2001 only. Banducci et al. (2009) examine the evolution of trust in the Euro, analysing how Europeans have perceived the inflationary effects of the transition to the new currency. Kaltenthaler et al. (2010) have evaluated the distrust of the public opinion in the ECB. They find that the distrust towards the ECB is stronger when people consider that the bank is too autonomous to reflect their own preferences. However, differently from our work here, they rely on a single survey wave (Eurobarometer 65.2 of 2006) and do not include any macroeconomic indicators as an 
explanatory variable. Moreover, distrust is considered with regard to the degree of independence the ECB enjoys, and not with regard to the policy it implements.

Studies of the macro-determinants of the trust in the ECB at a country level have also emerged. Fischer and Hahn (2008) show that higher inflation reduces the trust in the ECB. Roth (2009), Wälti (2012) and Gros and Roth (2014) have revisited such findings, in particular focusing on the impact of the GFC on the support for the ECB, and argue that the banking distress and the fiscal turmoil have affected negatively the degree of trust in the ECB. All these studies, however, completely ignore any socio-demographic determinants of support for the ECB, limiting attention to alternative macro-determinants, such as unemployment, inflation or GDP per capita. Only recently Ehrmann et al. (2013) have merged micro-data with macro-indicator dimensions in such an analysis, like we do, but their focus is on the fall in the trust in the ECB caused by the GFC in an immediate aftermath until the spring of 2010. They show empirically that it reflected (i) the deterioration in macroeconomic conditions, (ii) a general fall in the trust in all European institutions following the crisis and (iii) the severity of banking sector problems, as the ECB may be perceived to have been responsible for it.

The present paper, therefore, sets out to exploit the richness of the individual-based responses and characteristics in the Eurobarometer survey waves over the whole history of the ECB to date, notably highlighting trends over the post-GFC subperiod (2009-2015), which none of the cited studies do. A benefit of using survey data is that they provide an independent source of information about agents' perceptions. Consequently, one need not impose modelling assumptions to back out those perceptions. Also, as Ehrmann et al. (2013) state, using individual-level data allows controlling for the effect of different variables that influence trust in the ECB and identify the marginal effect at the individual level. In other words, one can control for unobserved heterogeneity and thus provide more reliable estimates. Our results confirm some of the findings in Ehrmann et al. (2013), e.g., about the statistical importance of age, gender, political orientation and educational attainment. Yet we expand this set to include also occupation status, income (where data allow it), and expectations about the economy, as well as a number of country-level institutional and historical features such as fiscal prudence and the experience of past hyperinflations. Since none of the studies we quoted, apart from Ehrmann et al. (2013), deals with blending micro-data with macro-data, our main contribution is to do so and compare their relative influence on trust in the ECB, as it evolves over time 
and with expanding EMU membership. In such a sense, our approach is more general and encompassing.

Methodologically too, there are many differences with respect to the closest literature. Fischer and Hahn (2008) express the country level of trust in the ECB as the share of "yes" responses in the national samples of the Eurobarometer survey, focusing on alternative annual proxies for the state of the macroeconomy lagged by a year. They apply a fixed-effects generalized least squares (GLS) estimator motivated by the nature of the dependent variable, measured in continuous percentage points. Wälti (2012) studies empirically, via panel data regressions using monthly data, country-level net trust in the ECB ("yes" responses minus "no" responses in the same survey) as a function of macroeconomic developments. He claims two innovations relative to the literature: (i) the linkage of the fall in net trust during the GFC to the large divergence of sovereign bond yields across the Euro area countries; (ii) since crises exhibit high-frequency dynamics, the use of monthly data as explanatory variables. Roth (2009) and Gros and Roth (2014) both also focus on the impact of the GFC on trust in the ECB, working with country-level net trust too. Gros and Roth (2014) estimate net trust in an unbalanced panel with country fixed effects as a function of quarterly adjusted inflation, or growth of GDP per capita, or unemployment, and control variables.

Differently, our aim is to compare econometrically the relative influence of individual sociodemographic characteristics as determinants of trust in the ECB over the whole period of its functioning with that of the usual country-level macro-determinants of trust in a central bank. We perform pseudo-panel logit estimation revealing that the former have a dynamically stable, and hence predictable, and if taken altogether stronger, influence than the latter in relative terms, as measured by the magnitudes of the respective statistically significant average marginal effect coefficients. Interestingly, we find that expected inflation becomes a positive determinant of trust in the ECB in the subperiod following the GFC, while actual inflation gets no statistical significance - neither in the pre-GFC, nor in the post-GFC subperiods. The interpretation we suggest is related to the excessive disinflation and risk of deflation which have taken centre stage in the monetary policy debate in the Euro area since early 2013. This debate has attracted condensed attention by the public and has without doubt affected its perceptions about the ECB. Our results seem to emphasise forward-looking behaviour of the EMU population with regard to potential 'deflation scares' in determining trust in the ECB as well as fiscal prudence among the macro-indicators that matter, in addition 
to disentangling and comparing the contributions of the key socio-demographic factors. These points are important because of their policy implications, in particular the need to target the ECB's communication strategy towards specific social groups.

The paper is further organised as follows. Section 2 describes the measurement and determinants of public trust in the ECB as well as our econometric approach. Section 3 then presents our baseline empirical results, and the final section concludes.

\section{Data, Measures and Trends}

Our data comes from the Eurobarometer survey. This survey, dealing with issues of general interest, is conducted on behalf of the European Commission since 1973. The results are published in Eurobarometer and are available on the Gesis website. ${ }^{3}$

\subsection{Measuring Trust in the ECB from the Eurobarometer Survey}

We have used Eurobarometer surveys 52.0 (November 1999) through 83.3 (May 2015), selecting those waves of the survey that include the question on trust in the ECB we are interested in. The waves of the survey we employ (see Table 1) cover all 19 current EMU member-countries (in Euro-area changing composition).

Among other questions, the respondents are asked about the importance of the major European institutions, including the ECB, and their trust in them, in particular in the ECB (e.g., Question 28_6 in Eurobarometer 52.0), which is of our direct interest here, as follows:

"Q.28 And, for each of them, please tell me if you tend to trust it or tend not to trust it? Q.28_6 The European Central Bank"

The responses are recorded in the following way: 1 for 'Tend to trust', 2 for 'Tend not to trust', and 3 for 'Don't know'. We measure the trust in the European Central Bank by transforming this categorical variable into a binary one, excluding the responses coded 3 that

\footnotetext{
${ }^{3}$ http://zacat.gesis.org/webview/index.jsp. For replication purposes, an additional *.zip file archive is available; it contains our STATA data set, codes and the respective input and output files.
} 
do not express an opinion. The binary discrete choice variable thus obtained becomes our dependent variable. However, just excluding the 'Don't know' category raises a problem, as people could be more interested in economic matters when things turn bad. In fact, we are able to confirm this countercyclical nature of the trust in the ECB: fewer people declare themselves in this third category near the end of our sample period. Moreover, it may also be that people decide first to express an opinion or not, and only then on what their opinion would be, creating a potential sample selection bias. For these reasons, two alternative estimations complemented our main one: (i) imputation to handle missing data in a way resulting in valid statistical inference (Rubin, 1987); (ii) two-step correction for sample selection bias (Heckman, 1976, 1979). The essence of the baseline results highlighted further below was preserved.

Our country sample contains all the current 19 EMU members (see figures 1 and 2). In order to look at the potential interesting dynamics in the support for the ECB that may be present across the length of our sample period, we report results on several time subsamples. Hence, we split the whole sample period in the following subperiods: before the last main EU enlargement (1999-2004), before the GFC (1999-2008), after the GFC (2009-2015), and the full period (1999-2015).

As can be seen in Figure 1, the average (across all included survey waves) national (within a given EMU member-country) level of trust in the ECB is higher in the Netherlands (75.2\%), Malta (74.8\%), Luxembourg (73.5\%) and Finland (70.1\%), where above $70 \%$ of the respondents tend to trust the ECB. By contrast, the weakest average support, below or just about $50 \%$, characterizes some of the countries with the deepest sovereign debt problems in the EMU such as Greece (45.2\%), Cyprus (46.5\%) and Spain (50.2\%) - but also France (49.8\%). Figure 1 also indicates the minimum and maximum (across all included survey waves) national (within a given EMU member-country) levels of trust in the ECB. 
Table 1. Included Eurobarometer Survey Waves

\begin{tabular}{|c|c|c|c|c|c|}
\hline $\begin{array}{l}\text { No. in Our } \\
\text { Sample }\end{array}$ & Original No. & $\begin{array}{l}\text { Original 4- } \\
\text { Digit Code }\end{array}$ & Period & Year & Year Wave \\
\hline 1 & 52.0 & 3204 & Oct-Nov & 1999 & 2nd \\
\hline 2 & 53.0 & 3296 & Apr-May & 2000 & $1 \mathrm{st}$ \\
\hline 3 & 54.1 & 3387 & Nov-Dec & 2000 & 2 nd \\
\hline 4 & 55.2 & 3507 & Apr-May & 2001 & $1 \mathrm{st}$ \\
\hline 5 & 56.2 & 3627 & Oct-Nov & 2001 & 2 nd \\
\hline 6 & 57.1 & 3639 & Mar-Apr & 2002 & $1 \mathrm{st}$ \\
\hline 7 & 58.1 & 3693 & Oct-Nov & 2002 & 2 nd \\
\hline 8 & 59.1 & 3904 & Mar-Apr & 2003 & $1 \mathrm{st}$ \\
\hline 9 & 60.1 & 3938 & Oct-Nov & 2003 & $2 \mathrm{nd}$ \\
\hline 10 & 61.0 & 4056 & Feb-Mar & 2004 & $1 \mathrm{st}$ \\
\hline 11 & 62.0 & 4229 & Oct-Nov & 2004 & 2nd \\
\hline 12 & 63.4 & 4411 & May-Jun & 2005 & $1 \mathrm{st}$ \\
\hline 13 & 64.2 & 4414 & Oct-Nov & 2005 & 2nd \\
\hline 14 & 65.2 & 4506 & Mar-Apr & 2006 & $1 \mathrm{st}$ \\
\hline 15 & 66.1 & 4526 & Sep-Oct & 2006 & 2nd \\
\hline 16 & 67.2 & 4530 & Apr-May & 2007 & $1 \mathrm{st}$ \\
\hline 17 & 68.1 & 4565 & Sep-Nov & 2007 & 2nd \\
\hline 18 & 69.2 & 4744 & Mar-May & 2008 & $1 \mathrm{st}$ \\
\hline 19 & 70.1 & 4819 & Oct-Nov & 2008 & 2 nd \\
\hline 20 & 71.3 & 4973 & Jun-Jul & 2009 & $1 \mathrm{st}$ \\
\hline 21 & 72.4 & 4994 & Oct-Nov & 2009 & 2nd \\
\hline 22 & 73.4 & 5234 & May & 2010 & $1 \mathrm{st}$ \\
\hline 23 & 74.2 & 5449 & Nov-Dec & 2010 & 2nd \\
\hline 24 & 75.3 & 5481 & May & 2011 & $1 \mathrm{st}$ \\
\hline 25 & 76.3 & 5567 & Nov & 2011 & 2nd \\
\hline 26 & 77.3 & 5612 & May & 2012 & $1 \mathrm{st}$ \\
\hline 27 & 78.1 & 5685 & Nov & 2012 & 2 nd \\
\hline 28 & 79.3 & 5689 & May & 2013 & $1 \mathrm{st}$ \\
\hline 29 & 80.1 & 5876 & Nov & 2013 & $2 \mathrm{nd}$ \\
\hline 30 & 81.2 & 5913 & Mar & 2014 & $1 \mathrm{st}$ \\
\hline 31 & 81.4 & 5928 & May-Jun & 2014 & 2nd \\
\hline 32 & 82.3 & 5932 & Nov & 2014 & $3 \mathrm{rd}$ \\
\hline 33 & 83.3 & 5998 & May & 2015 & $1 \mathrm{st}$ \\
\hline
\end{tabular}


Figure 1. Average National Support for the ECB by Current EMU Member-Country, \%

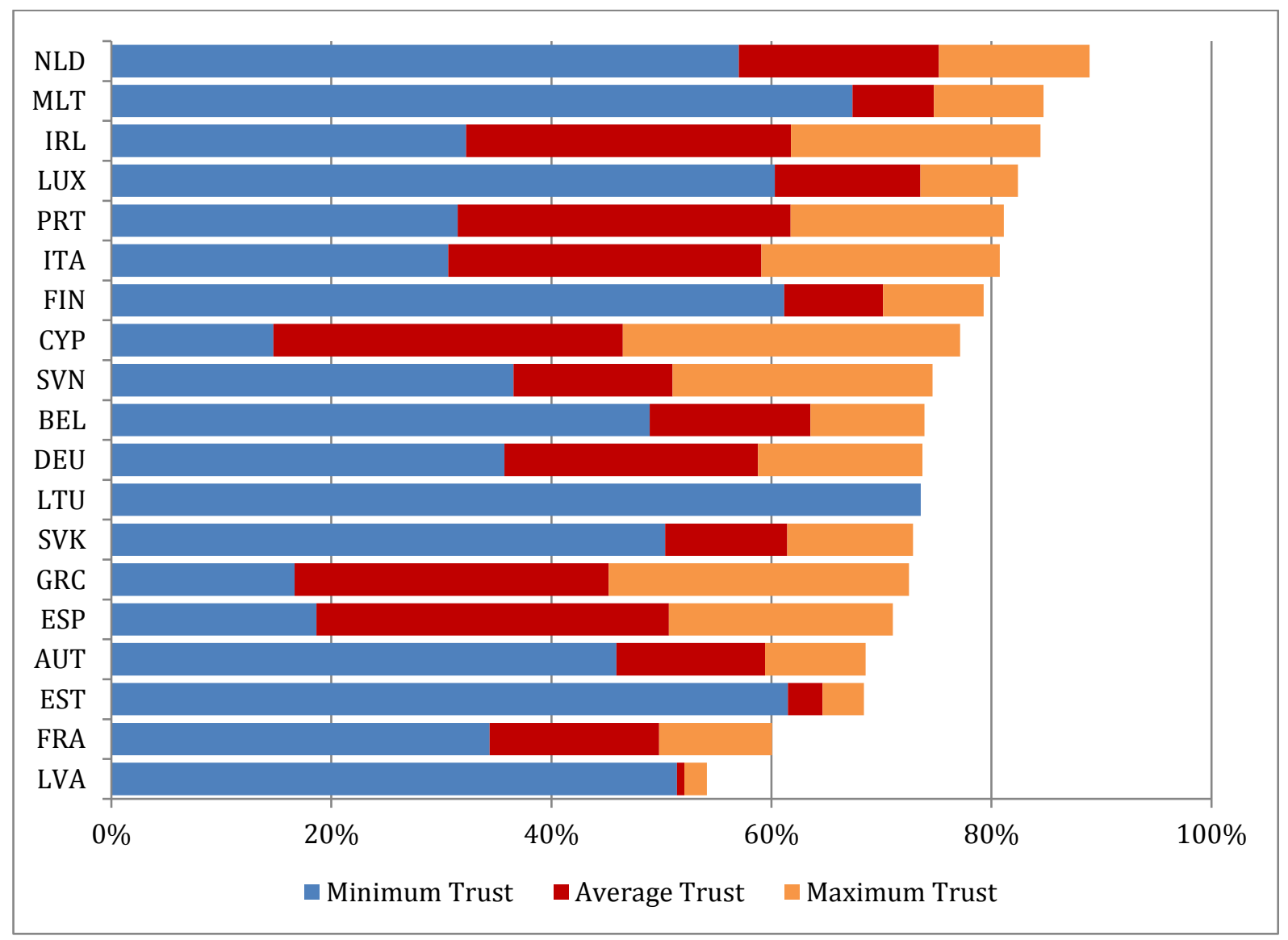

Source: Authors' calculations, from Eurobarometer survey data.

Note: As Lithuania joined the EMU in 2015, we have only one survey for it in our sample. That is why only one value for Lithuania $($ minimum $=$ maximum $=$ average $)$ is displayed in the LTU bar of the figure .

Figure 2 presents the dynamics of trust in the ECB by Eurobarometer survey waves in each of the 19 current EMU member-countries. A general trend is that trust in the ECB has declined in all EMU member-states post-GFC relative to pre-GFC. While in about one third of the countries in our sample this decline has been relatively smooth and shallow (alphabetically, Austria, Belgium, Finland, Malta, the Netherlands, Slovakia) in, roughly, another third, essentially those most heavily affected by the Euro-area debt crisis, it has been sharp and deep (Cyprus, Greece, Ireland, Italy, Slovenia, Spain, Portugal), with the remaining last third of the EMU member-states displaying a trust evolution profile that falls somewhere in-between.

The summary statistics on the trust in the ECB by socio-demographic category in our EMU sample are displayed in Table 2 and give a preview of some of the tendencies and results we 
shall be discussing when analysing the estimated regressions later on. In particular, trust in the ECB tends to increase its mean (in percentage terms) with higher education, income, and optimism of economic expectations; also, the unemployed trust the ECB the least (in relative percentage terms), and female EMU citizens trust the ECB less than male EMU citizens. We next propose justification for considering these determinants of public trust in the ECB, whereas interpretation of the noted tendencies follows in the later sections.

Figure 2. Evolution of Trust in the ECB by Current EMU Member-Country, \%

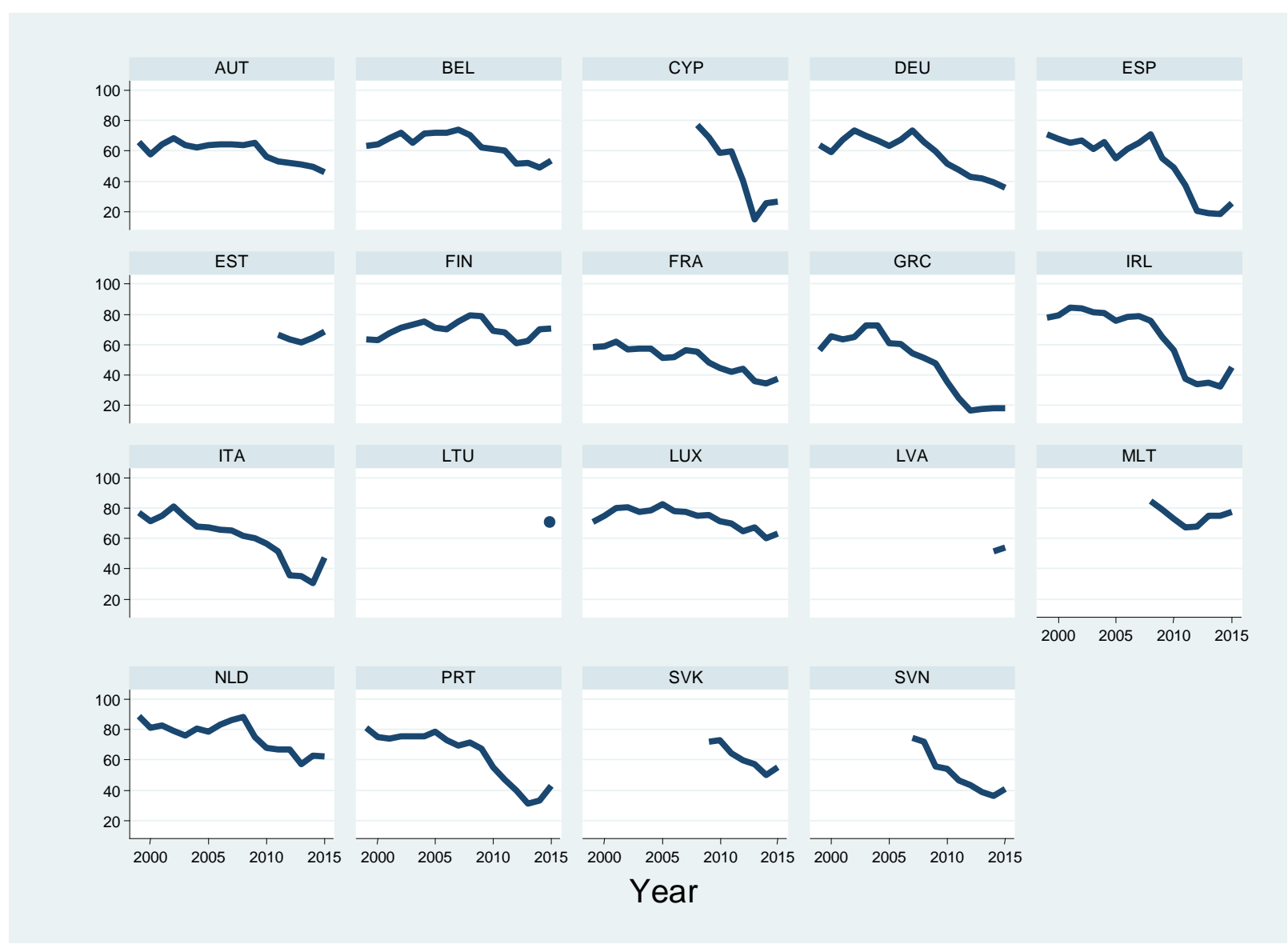

Source: Authors' calculations based on Eurobarometer survey data.

Note: Again, as Lithuania joined the EMU in 2015, we have only one survey for it in our sample. That is why dynamics is not displayed in the LTU panel of the figure. 
Table 2. Trust in the ECB by Socio-Demographic Category - Summary Statistics

\begin{tabular}{|c|c|c|c|}
\hline & Mean & Std.Dev. & Obs. \\
\hline Full Sample & 0.59 & 0.49 & 382,951 \\
\hline \multicolumn{4}{|l|}{ Gender } \\
\hline Male & 0.61 & 0.48 & 186,003 \\
\hline Female & 0.57 & 0.49 & 196,948 \\
\hline \multicolumn{4}{|l|}{ Age } \\
\hline $15-24$ & 0.64 & 0.48 & 45,628 \\
\hline $25-44$ & 0.59 & 0.49 & 129,664 \\
\hline $45-64$ & 0.58 & 0.49 & 129,923 \\
\hline $65+$ & 0.58 & 0.49 & 77,735 \\
\hline \multicolumn{4}{|l|}{ Education } \\
\hline Up to 15 & 0.51 & 0.50 & 84,586 \\
\hline $16-19$ & 0.57 & 0.49 & 154,186 \\
\hline $20+$ & 0.66 & 0.47 & 107,915 \\
\hline Still studying & 0.67 & 0.47 & 31,200 \\
\hline \multicolumn{4}{|c|}{ Political Placement } \\
\hline Left & 0.62 & 0.48 & 83,728 \\
\hline Center & 0.64 & 0.47 & 108,481 \\
\hline Right & 0.67 & 0.47 & 64,753 \\
\hline \multicolumn{4}{|c|}{ Economic Expectations } \\
\hline Better & 0.70 & 0.45 & 72,267 \\
\hline Same & 0.61 & 0.49 & 129,021 \\
\hline Worse & 0.48 & 0.50 & 134,139 \\
\hline \multicolumn{4}{|l|}{ Income } \\
\hline Q1 & 0.64 & 0.48 & 14,277 \\
\hline Q2 & 0.69 & 0.46 & 16,066 \\
\hline Q3 & 0.72 & 0.45 & 16,192 \\
\hline Q4 & 0.76 & 0.42 & 15,976 \\
\hline \multicolumn{4}{|l|}{ Occupation } \\
\hline Unemployed & 0.43 & 0.50 & 28,128 \\
\hline Retired & 0.57 & 0.49 & 97,197 \\
\hline
\end{tabular}

Source: Authors' calculations based on Eurobarometer survey data. 


\subsection{Determinants of Trust}

In accordance with the literature, we include in our estimates the major macroeconomic determinants of trust in the ECB, such as inflation (actual or expected) or, alternatively, unemployment or real GDP growth, as well as national economic or institutional dummies to capture the effects of past hyperinflation episodes and fiscal prudence (or lack of it) as per the criteria in the Stability and Growth Pact (SGP). To these macro-determinants, we add and jointly estimate key micro-determinants, namely, socio-demographic characteristics measured through categorical variables covering the following dimensions: education, income, employment status, economic expectations, political placement, gender, and age of the respondents.

Macroeconomic variables - such as inflation, real GDP growth, the unemployment rate and some transformations of these variables (lags or other) - have been shown to matter in the related studies cited above, but mostly when considered in isolation from socio-demographic determinants of central bank trust. Given that the ECB has price stability as its primary goal, and communicates it clearly to the public, actual inflation is the most natural macroeconomic determinant of trust in the ECB to be considered in our estimation. ${ }^{4}$ Data on inflation comes from the Eurostat, measured as the annual percentage change in the Harmonized Index of Consumer Prices (HICP). Focusing attention on actual inflation as the key business cycle control variable is even more important with regard to the question at hand, because inflation experience can strongly shape people's preferences and, thus, their attitudes to the central bank, as Erhmann and Tzamourani (2012) show.

With respect to the key socio-demographic determinants of trust, Walstad and Rebeck (2002) observe that education is an important determinant of an individual's preference concerning an economic issue, as well as measuring labour market skills and cognitive abilities (Scheve, 2004). However, there is no consensus about the effect of education on an economic issue: for instance, Hainmüller and Hiscox (2006) find that people with college education are more protrade while other forms of education are not significant in evaluating trade policy. In our case,

\footnotetext{
${ }^{4}$ Nevertheless, preliminary estimates with lags of the inflation rate, with inflation and inflation squared, or replacing inflation by GDP growth (lagged or not) or by unemployment (lagged or not) delivered similar qualitative results. Hence, for the sake of brevity, we only report here estimates with inflation, initially, but complement these, subsequently, with estimates when actual inflation is replaced by inflation expectations.
} 
we assume education to be linked to an understanding of the costs of inflation and of the macroeconomic role and institutional mandate of the central bank. Education would thus be one main determinant of support for the ECB. ${ }^{5}$

Then, individual income proved influential in Jayadev (2006) for people's attitude towards inflation. In our case, income is hypothesised to pertain to an individual's self-interest: for example, if they own nominal assets and aim to preserve their purchasing power. Such a motivation suggests that individual income should be among the main socio-demographic determinants of support for the ECB. ${ }^{6}$ Although income and education would generally be correlated, disaggregating the data within each of these two explanatory variables, as we do and discuss further down, possibly reduces the effects of such a correlation, allowing us to separate out the respective influences of the underlying components.

The literature has also suggested that employment status could be important, with the unemployed people less supportive of a central bank focusing too much on inflation, as low inflation levels could lead to a distortion of the Phillips curve trade-off (see Akerlof et al., 1996). Such a distortion may push up the sacrifice ratio, and be perceived as costly, in particular by the unemployed and retired people. We therefore include occupation dummies for the unemployed and the retired. Moreover, as the probability of being unemployed, or to have one's income reduced, is linked to business cycles fluctuations, we also take into account the economic expectations the surveyed declare.

Previous studies (Nelsen and Guth, 2000; Scheve, 2004) have revealed that women are less concerned about economic issues, so we add gender in our regressions. Age can also be important with respect to inflation aversion and, hence, central bank independence issues related to the role of the ECB. Farvaque and Mihailov (2009) and Farvaque et al. (2010) show that an older population acts as a strong weight against inflation, while Malmendier and Nagel (2015) present evidence that individuals of different ages react differently to past inflation experiences. The latter study points to the need to also consider the experience of hyperinflation some people might have lived through. We therefore include in our estimates a

\footnotetext{
${ }^{5}$ Yet, we acknowledge the potentially ambiguous interpretation regarding the effect of education in our context too. More educated people may be observing more critically how the ECB is performing. If they think that the ECB is not doing a good job, trust may weaken.

${ }^{6}$ Ideally, data on wealth and on asset detention would be preferable, but are not available.
} 
dummy variable with value 1 if the country has known a hyperinflation episode in the 20th century. ${ }^{7}$ As monetary policy outcomes (in the extreme, hyperinflation episodes) are related to fiscal policy outcomes (Fischer et al., 2002) and, more importantly, to account for the fulfilment of the SGP fiscal criteria, we include two other country-level dummies: SGPDEBT has a value equal to 1 if the country shows a public debt to GDP ratio superior to the $60 \%$ limit, while SGPDEF is equal to 1 if the country shows a public deficit to GDP ratio superior to the $3 \%$ threshold. To explore potential differences in the opinion of the main subgroups of current EMU member-countries, we also add dummies for the original 6 members of the EU, denoted EU6, ${ }^{8}$ the subsequent 12 members of the EU, EU12, ${ }^{9}$ and for the 'newcomers' with the big EU enlargement in 2004, EU2004. ${ }^{10}$

We further include political characteristics of the respondents. In the surveys we use, a political placement indicator approximates political ideology. Political orientation can obviously change individual attitudes towards important economic issues and institutions, including inflation and the central bank. Finally, as trust in the ECB could be related to an overall pro-EU attitude, we also add a dummy variable to capture trust in the European Commission, constructed out from the Eurobarometer survey. ${ }^{11}$

\subsection{Econometric Issues and Methodology}

Since our dependent variable is a binary categorical variable - taking the values of 1 and 0 according to whether a particular respondent tends to trust or not, respectively, the European Central Bank - a survey-based quasi-panel logistic regression model is well suited for our purpose. ${ }^{12}$ In our baseline, we include time fixed effects but exclude country fixed effects, in order to obtain meaningful estimates of the hypothesised country-level macro-determinants alongside with the micro-determinants of trust in the ECB. In the Eurobarometer survey data

\footnotetext{
${ }^{7}$ In our sample, this is the case for Germany and Greece in the immediate aftermath of World War I and/or II and for Slovenia during its transition from a centrally-planned to market economy in the early 1990s.

${ }^{8}$ Belgium, France, Germany, Italy, Luxembourg and the Netherlands.

${ }^{9}$ Belgium, Denmark, France, Germany, Great Britain, Greece, Ireland, Italy, Luxembourg, the Netherlands, Portugal and Spain.

${ }^{10}$ The Republic of Cyprus, the Czech Republic, Estonia, Hungary, Latvia, Lithuania, Malta, Poland, Slovakia and Slovenia.

${ }^{11}$ This aspect is also addressed in Ehrmann et al. (2013). Further analysis comparing trust in the ECB with trust in the European Commission and the European Parliament as dependent variable in support of the robustness of the results we report later on regarding trust in the ECB can be found in the working paper version of the present article, Farvaque et al. (2011).

${ }^{12}$ Note that the Eurobarometer survey is not a true panel, as respondents change in each wave.
} 
we employ, any time-invariant framing effects will also be country-specific. ${ }^{13}$ As is standard in panel-data analysis, time fixed effects are meant to control for unobserved aggregate shocks that would otherwise introduce omitted variable bias and impair statistical inference. ${ }^{14}$

Our baseline empirical model therefore takes the following form: ${ }^{15}$

$$
\operatorname{Trust}_{i(t) j}=f\left(\operatorname{Inf}_{j t} ; \operatorname{Dem}_{i(t) j} ; \operatorname{Pol}_{i(t) j} ; \operatorname{EcoExp}_{i(t) j} ; D^{\prime}{ }_{j t} ; T_{t} ; c\right)+\varepsilon_{i(t) j}
$$

where

$$
\begin{aligned}
& \operatorname{Dem}^{\prime}{ }_{i(t) j}=\left(G D_{i(t) j} ; \operatorname{Age}_{i(t) j j} ; E d u 4_{(t) j} ; U D_{i(t) j} ; R D_{i(t) j} ;\left[\operatorname{Inc}_{i(t) j]}\right)^{\prime}\right. \\
& \text { Pol' }_{i(t) j}=\left(\operatorname{Pol}_{i(t) j} ; E C D_{i(t) j}\right)^{\prime} \\
& D^{\prime}{ }_{j t}=\left(\text { Hyperinflation }_{j t} ; \text { SGPDEBT }_{j t} ; \operatorname{SGPDEF}_{j t} ; E U 6_{j t} ; E U 12_{j t} ; E U 2004_{j t}\right){ }^{\prime} \text {, }
\end{aligned}
$$

and Trust $_{i(t) j}$ is the opinion of a respondent $i$ at time/wave $t$ of the Eurobarometer survey in country $j$. Inf $f_{j t}$ is the measure of actual or expected inflation at $t$ in country $j .{ }^{16}$

The 'demographic' vector $D e{ }^{\prime}{ }_{i(t) j}$ contains the gender of the $i$-th respondent to the $t$-th survey wave in the $j$-th country, the dummy $G D_{i(t) j}$, and other categorical variables: Age $4_{i(t) j}$ is the age group of the respondent in 4 ordered categories: 15-24 years, 25-44 years, 45-64 years, $65+$ years; $E d u 4_{(t) j}$ is the education level of the respondent in 4 ordered categories: up to 15 years of age at the time of obtaining the highest degree, 16-19 years, 20+ years, still studying; $U D_{i(t) j}$ is the dummy for the unemployed and $R D_{i(t) j}$ for the retired; Inc $4_{i(t) j}$ is the income quartile of the respondent (hence, in 4 ordered categories).

\footnotetext{
${ }^{13}$ For an alternative estimation with both time and country fixed effects that is meant to isolate away all aggregate variation in the data and, thus, check robustness with regard to distinguishing which micro-factors are most important, the interested reader is referred to the working paper version, Farvaque et al. (2011). The results we report further below regarding the relative influence of the socio-demographic determinants of trust in the ECB are not affected significantly in qualitative and quantitative terms if country fixed effects are added.

${ }^{14}$ Wälti (2012) argues in favour of an estimation strategy with both country and time fixed effects, but his regressions do not include socio-demographic explanatory variables. He focuses only on macro-determinants of trust in the ECB in an earlier sample of 12 EMU economies, while we look at both macro- and micro-factors for all current 19 EMU member-countries.

${ }^{15}$ The data by income quartiles is not available for the whole sample period, but only up through 2004 . We denote this in the equations below by the use of square brackets. The statistical significance and economic importance of this key explanatory variable in our context have been checked by excluding/including it in alternative specifications.

${ }^{16}$ In our empirical implementation, actual inflation is approximated by the average HICP annual inflation rate in the respective year of the Eurobaromater survey, and expected inflation is one year ahead. The definition and source of inflation expectations in the Euro area are taken from the ECB Survey of Professional Forecasters (SPF), with the data available online at http://www.ecb.int/stats/prices/indic/forecast/html/index.en.html.
} 
The 'political' vector $P o l_{i(t) j}$ contains the trust in the EU Commission dummy, $E C D_{i(t) j}$, and an ordered categorical variable, Pol3 $i(t) j$, accounting for the political placement of the respondent in 3 categories: left, centre and right.

$E c o E x p 3_{i(t) j}$ indicates the expectation of the respondents about the economic situation in the next twelve months, with response options given by 'better', 'worse' or 'same'.

Time (year) fixed effects, $T_{t}$, capture trends common to all countries, such as the GFC. $\varepsilon_{i(t) j}$ is the individual disturbance in the regression, $c$ the constant term. We also add other dummies (already defined), $D^{\prime}{ }_{j t}$, in the versions of (1) we estimated, as explained above.

In line with most of the micro-econometric literature involving binary-choice dependent variables, we estimate the parameters of our general empirical model in (1) using dynamic logit regressions. We, in effect, assume that our measure of trust in the ECB, $\operatorname{Trust}_{i(t) j} \equiv Y_{i(t) j}-$ which could be thought of as the conditional probability of a 'yes' response $P\left(Y_{i(t) j}=1 \mid x_{i(t) j)}\right.$ to the relevant survey question given the covariates, or 'predictors', collected in the vector of explanatory variables, $x_{i(t) j}$ - more specifically follows a logistic distribution, so that:

$$
P\left(Y_{i(t) j}=1 \mid x_{i(t) j}\right)=\frac{1}{1+e^{-\left(c+T_{t}+\beta^{\prime} x_{i(t) j}\right)}}
$$

Then, a higher level of $c+T_{t}+\beta^{\prime} x_{i(t) j}$ would imply a higher level of trust for the particular definition of the employed (sub)sample, with $\beta$ denoting the vector of estimated coefficients. Since we are merging country-level inflation and dummies with micro-data, it is important to consider the possibility that disturbances will be correlated across countries. Hence, standard errors are clustered by country and require the much weaker assumption that errors are independent across countries but not necessarily across survey respondent within a country (Moulton, 1990).

Another issue in the analysis is the weighting of the survey data. We followed the proposal of DuMouchel and Duncan (1983) to include sampling weights and interaction terms between the weights and the independent variables in the regressions to detect possible misspecifications. In almost all cases, we could not reject the hypothesis that the coefficients 
of the sampling weights and the interaction terms were equal to zero. This indicated that our results are not sensitive to the weighting, and thus we base their reporting on unweighted data.

To observe whether variations in the support for the ECB occur over time, we split our full sample period (1999-2015) across several subperiods: 1999-2004 (pre-EU enlargement), 1999-2008 (pre-GFC), 2009-2015 (post-GFC).

\section{Results on the Determinants of Trust in the ECB and Their Evolution}

\subsection{Baseline Regressions}

Assuming the logistic distribution in (2), we estimate our baseline nonlinear regression (1) by maximum likelihood. Table 3 presents the results from an initial specification where we use actual inflation as the key macro-determinant of trust in the ECB. Apart from average marginal effects by covariate, with their respective standard errors and significance levels, we report as a goodness-of-fit measure for each of our alternative specifications the McFadden's (1974) Pseudo- $\mathrm{R}^{2}$, computed in the usual way,

$$
0<\text { Pseudo } R^{2} \equiv 1-\frac{\mathcal{L}_{1}}{\mathcal{L}_{0}}<1
$$

where $\mathcal{L}_{1}$ is the log-likelihood of the estimated specification while $\mathcal{L}_{0}$ is the log-likelihood of a 'null' model including only a constant term.

As was noted, the Eurobarometer surveys discontinue publishing the income quartile characteristics of the respondents after 2004. For this reason, income quartiles appear only in specification/column (1) in Table 3 and the following tables, and not when estimates are reported up through 2008 or 2015 . Such a discontinuity causes concern, though, as our results confirm that income is a significant and positive determinant of trust in the ECB. More precisely, trust in the ECB is an increasing function of income (quartile), implying that ECB's communication needs to be tailored to different income categories. 
Nevertheless, comparing specifications $(0)$ and (1) in Table 3, we can say that although accounting for income quartiles is clearly justified, it does not modify substantively the other results. That is, specifications $(0)$ and (1) contain exactly the same statistically significant variables in terms of sign, while magnitudes may minimally change. Each of these specifications explains about one-third of the variation in the dependent variable, a relatively large proportion for similar micro-econometric studies. ${ }^{17}$

Table 3. Baseline Regression Results Using Actual Inflation

\begin{tabular}{|c|c|c|c|c|c|}
\hline & (0) & (1) & (2) & (3) & (4) \\
\hline & 1999-2004 & 1999-2004 & 1999-2008 & $2009-2015$ & $1999-2015$ \\
\hline \multirow[t]{2}{*}{ Actual Inflation } & 0.010 & 0.014 & -0.002 & 0.003 & 0.002 \\
\hline & $(0.007)$ & $(0.010)$ & $(0.008)$ & $(0.005)$ & $(0.005)$ \\
\hline \multirow[t]{2}{*}{ Gender Dummy (BL: Male) } & $-0.023 * * *$ & $-0.018 * * *$ & $-0.031 * * *$ & $-0.034 * * *$ & $-0.032 * * *$ \\
\hline & $(0.004)$ & $(0.004)$ & $(0.005)$ & $(0.007)$ & $(0.006)$ \\
\hline \multicolumn{6}{|l|}{$\operatorname{Age}(B L: 15-24)$} \\
\hline \multirow[t]{2}{*}{$25-44$} & 0.007 & 0.000 & 0.010 & $0.010 * *$ & $0.008 *$ \\
\hline & $(0.011)$ & $(0.010)$ & $(0.007)$ & $(0.005)$ & $(0.005)$ \\
\hline \multirow[t]{2}{*}{$45-64$} & 0.020 & 0.010 & $0.031 * * *$ & $0.026 * * *$ & $0.026 * * *$ \\
\hline & $(0.012)$ & $(0.010)$ & $(0.010)$ & $(0.007)$ & $(0.007)$ \\
\hline \multirow[t]{2}{*}{$65+$} & 0.017 & 0.012 & $0.037 * * *$ & $0.048 * * *$ & $0.039 * * *$ \\
\hline & $(0.014)$ & $(0.012)$ & $(0.012)$ & $(0.011)$ & $(0.010)$ \\
\hline \multicolumn{6}{|l|}{ Education (BL: Up to 15) } \\
\hline \multirow[t]{2}{*}{$16-19$} & $0.016 *$ & 0.006 & $0.027 * * *$ & $0.026 * * *$ & $0.027 * * *$ \\
\hline & $(0.008)$ & $(0.009)$ & $(0.009)$ & $(0.006)$ & $(0.007)$ \\
\hline \multirow[t]{2}{*}{$20+$} & $0.044 * * *$ & $0.023 * *$ & $0.066 * * *$ & $0.066 * * *$ & $0.065 * * *$ \\
\hline & $(0.010)$ & $(0.009)$ & $(0.012)$ & $(0.013)$ & $(0.012)$ \\
\hline \multirow[t]{2}{*}{ Still studying } & 0.017 & -0.000 & $0.037 * * *$ & $0.029 * * *$ & $0.031 * * *$ \\
\hline & $(0.012)$ & $(0.012)$ & $(0.011)$ & $(0.011)$ & $(0.009)$ \\
\hline \multicolumn{6}{|l|}{ Political Placement (BL: Left) } \\
\hline \multirow[t]{2}{*}{ Centre } & $0.027 * * *$ & $0.025 * * *$ & $0.023 * * *$ & $0.012 * * *$ & $0.017 * * *$ \\
\hline & $(0.006)$ & $(0.006)$ & $(0.005)$ & $(0.004)$ & $(0.004)$ \\
\hline \multirow[t]{2}{*}{ Right } & $0.031 * * *$ & $0.028 * * *$ & $0.030 * * *$ & $0.029 * * *$ & $0.029 * * *$ \\
\hline & $(0.006)$ & $(0.006)$ & $(0.006)$ & $(0.005)$ & $(0.005)$ \\
\hline \multicolumn{6}{|l|}{ Occupation Dummies } \\
\hline \multirow[t]{2}{*}{ Unemployed } & $-0.037 * * *$ & $-0.027 * *$ & $-0.032 * * *$ & $-0.035 * * *$ & $-0.033 * * *$ \\
\hline & $(0.010)$ & $(0.010)$ & $(0.009)$ & $(0.008)$ & $(0.007)$ \\
\hline \multirow[t]{2}{*}{ Retired } & 0.000 & 0.008 & -0.004 & $-0.012 * *$ & $-0.007 *$ \\
\hline & $(0.006)$ & $(0.006)$ & $(0.004)$ & $(0.005)$ & $(0.004)$ \\
\hline \multicolumn{6}{|c|}{ Economic Expectations (BL: Same) } \\
\hline \multirow[t]{2}{*}{ Better } & $0.014 * *$ & $0.016 * * *$ & $0.018 * * *$ & $0.030 * * *$ & $0.027 * * *$ \\
\hline & $(0.007)$ & $(0.005)$ & $(0.005)$ & $(0.007)$ & $(0.006)$ \\
\hline \multirow[t]{2}{*}{ Worse } & $-0.047 * * *$ & $-0.045 * * *$ & $-0.044 * * *$ & $-0.040 * * *$ & $-0.042 * * *$ \\
\hline & $(0.007)$ & $(0.008)$ & $(0.006)$ & $(0.008)$ & $(0.005)$ \\
\hline
\end{tabular}

\footnotetext{
${ }^{17}$ Note that we cannot compare such goodness of fit in a directly relevant way to similar studies, e.g., with regard to Ehrmann et al. (2013), since they do not report pseudo R-square for their probit regressions.
} 


\begin{tabular}{|c|c|c|c|c|c|}
\hline \multirow{2}{*}{ Q2 } & & $0.029 * * *$ & & & \\
\hline & & $(0.007)$ & & & \\
\hline \multirow[t]{2}{*}{ Q3 } & & $0.037 * * *$ & & & \\
\hline & & $(0.007)$ & & & \\
\hline \multirow[t]{2}{*}{ Q4 } & & $0.062 * * *$ & & & \\
\hline & & $(0.006)$ & & & \\
\hline \multicolumn{6}{|l|}{ Other Dummies } \\
\hline \multirow{2}{*}{ Trust in EU Commission } & $0.381 * * *$ & $0.383 * * *$ & $0.386^{* * * *}$ & $0.404 * * *$ & $0.397 * * *$ \\
\hline & $(0.009)$ & $(0.010)$ & $(0.008)$ & $(0.003)$ & $(0.005)$ \\
\hline \multirow[t]{2}{*}{ SGPDEF } & $-0.065^{* * *}$ & $-0.068 * * *$ & $-0.066 * *$ & $-0.052 * *$ & $-0.061 * * *$ \\
\hline & $(0.025)$ & $(0.024)$ & $(0.029)$ & $(0.021)$ & $(0.021)$ \\
\hline \multirow[t]{2}{*}{ SGPDEBT } & -0.014 & -0.021 & $-0.039 * *$ & $-0.048 *$ & $-0.041 * *$ \\
\hline & $(0.015)$ & $(0.014)$ & $(0.018)$ & $(0.028)$ & $(0.020)$ \\
\hline \multirow[t]{2}{*}{ Hyperinflation } & 0.032 & 0.034 & -0.011 & 0.011 & 0.015 \\
\hline & $(0.026)$ & $(0.029)$ & $(0.020)$ & $(0.021)$ & $(0.019)$ \\
\hline \multirow[t]{2}{*}{ EU6 } & 0.005 & 0.018 & 0.011 & 0.005 & 0.010 \\
\hline & $(0.020)$ & $(0.022)$ & $(0.022)$ & $(0.019)$ & $(0.020)$ \\
\hline \multirow[t]{2}{*}{ EU12 } & & & 0.014 & -0.047 & -0.028 \\
\hline & & & $(0.038)$ & $(0.031)$ & $(0.032)$ \\
\hline \multirow[t]{2}{*}{ EU2004 } & & & $0.064 * *$ & -0.001 & 0.010 \\
\hline & & & $(0.030)$ & $(0.023)$ & $(0.021)$ \\
\hline Observations & 48,129 & 29,297 & 112,930 & 110,504 & 205,575 \\
\hline Pseudo R-Square & 0.32 & 0.31 & 0.33 & 0.41 & 0.38 \\
\hline
\end{tabular}

Notes: The table provides logit regression results on the determinants of trust in the ECB in the EMU membercountries (changing composition), estimated using equation (1). Coefficients report the average marginal effects, with standard errors clustered by country in parentheses. BL: Base levels for the categorical variables. *, **, and $* * *$ denote statistical significance at the 10,5 , and 1 percent levels, respectively (two-tailed tests).

Our results further indicate that women trust less the ECB than men, and that older people accord stronger support to the ECB than younger ones. Also, trust in the ECB tends to increase with education levels and as one goes from 'left' through 'centre' and to 'right' in the political spectrum. The latter finding might have been expected given that the European Central Bank is generally considered as a rather conservative institution. Unemployed people trust the ECB less than employed people; the retired dummy becomes significant only when longer samples are considered, showing that retired people also tend to trust the ECB less than people at work (although the estimated average marginal effect is smaller than for unemployed). Those individuals who maintain pro-European views, in the sense of having higher trust in EU institutions such as the European Commission, display higher trust in the ECB as well. Among the socio-demographic variables with the strongest estimated average marginal effects on the support for the ECB by the European population at large are, notably, the higher-level education, the unemployment status, the two top income quartiles, and the centre- to-right political orientation. 
Economic expectations are strongly significant too, with the expected sign: the better the expected future, the higher the degree of trust in the ECB, as its monetary policy is generally perceived to influence the EMU macroeconomy. Citizens from countries with high fiscal deficits and debts tend to trust the ECB less than citizens from the remaining EMU memberstates, with the estimated average marginal effect of public debt being inferior to that of the public budget deficit (which may be a more 'visible' or discussed variable than debt).

Although it has already been documented that the global financial crisis has decreased trust in the ECB (Ehrmann et al., 2013; Gros and Roth, 2014), our results shed new light on this evolution, by going deeper and revealing the categories among which trust has decreased more. Comparing the results displayed in columns (2) through (4) in Table 3 allows looking at the evolution of support over time and categories. It appears that the support from the working-age population with more experience (age 45-64) and from the 'still studying' part of the population has eroded significantly post-GFC. An interesting observation is also that the respondents who are confident in the European Commission increased their trust in the ECB during this period.

Somewhat surprisingly, actual inflation is not statistically significant, even at the $10 \%$ level, in all our estimated specifications in Table 3. This result differs from the findings in Wälti (2012), but he considers only macro-determinants and not socio-demographic factors. Our result also differs from the findings in some - but not all - of the specifications in Ehrmann et al. (2013), where inflation and unemployment are both included in the estimated probit regressions in addition to socio-demographic determinants in their Eurobarometer survey sample much shorter (1999-2010) and narrower (12 EMU member-countries only versus the remaining non-EMU EU member countries) from the ones we report here. In our case, the addition of socio-demographic variables seems not just to complement but rather to 'overshadow' the influence of a key macroeconomic variable such as inflation as potential determinants of trust in the ECB. However, as can also be verified in the results of Ehrmann et al. (2013) for various subsample specifications and various sets of explanatory variables included, the statistical insignificance of observed inflation is not robust, hence not that much surprising. ${ }^{18}$ Nevertheless, to address a potential sensitivity of such findings to the relevant

\footnotetext{
${ }^{18}$ It could be argued that inflation does not appear significant because of the relatively low level of inflation in the Euro area, its low variance during our sample period, and the fact that the Euro area is also characterized by
} 
proxy for perceived inflation, we proceeded by replacing actual inflation with inflation expectations. The resulting estimates are reported in Table 4.

Table 4. Regression Results Using Expected Inflation

\begin{tabular}{|c|c|c|c|c|}
\hline & $(1)$ & $(2)$ & (3) & $(4)$ \\
\hline & 1999-2004 & 1999-2008 & $2009-2015$ & 1999-2015 \\
\hline \multirow[t]{2}{*}{ Expected Inflation } & 0.015 & 0.007 & $0.125 * * *$ & $0.115 * * *$ \\
\hline & $(0.030)$ & $(0.026)$ & $(0.016)$ & $(0.014)$ \\
\hline \multirow{2}{*}{ Gender Dummy (BL: Male) } & $-0.019 * * *$ & $-0.031 * * *$ & $-0.035 * * *$ & $-0.034 * * *$ \\
\hline & $(0.004)$ & $(0.005)$ & $(0.007)$ & $(0.006)$ \\
\hline \multicolumn{5}{|l|}{$\operatorname{Age}(B L: 15-24)$} \\
\hline \multirow[t]{2}{*}{$25-44$} & 0.000 & 0.011 & 0.007 & 0.003 \\
\hline & $(0.010)$ & $(0.007)$ & $(0.005)$ & $(0.005)$ \\
\hline \multirow[t]{2}{*}{$45-64$} & 0.011 & $0.032 * * *$ & $0.021 * *$ & $0.016 * *$ \\
\hline & $(0.010)$ & $(0.010)$ & $(0.008)$ & $(0.008)$ \\
\hline \multirow[t]{2}{*}{$65+$} & 0.014 & $0.038 * * *$ & $0.039 * * *$ & $0.024 * *$ \\
\hline & $(0.012)$ & $(0.012)$ & $(0.012)$ & $(0.011)$ \\
\hline \multicolumn{5}{|l|}{ Education (BL: Up to 15) } \\
\hline \multirow[t]{2}{*}{$16-19$} & 0.006 & $0.028 * * *$ & $0.022 * * *$ & $0.020 * * *$ \\
\hline & $(0.010)$ & $(0.009)$ & $(0.006)$ & $(0.007)$ \\
\hline \multirow[t]{2}{*}{$20+$} & $0.023 * *$ & $0.067 * * *$ & $0.056 * * *$ & $0.052 * * *$ \\
\hline & $(0.010)$ & $(0.012)$ & $(0.014)$ & $(0.012)$ \\
\hline \multirow[t]{2}{*}{ Still studying } & -0.002 & $0.038 * * *$ & 0.016 & $0.017 * *$ \\
\hline & $(0.011)$ & $(0.011)$ & $(0.011)$ & $(0.009)$ \\
\hline \multicolumn{5}{|l|}{ Political Placement (BL: Left) } \\
\hline \multirow[t]{2}{*}{ Centre } & $0.025 * * *$ & $0.023 * * *$ & $0.009 * *$ & $0.015 * * *$ \\
\hline & $(0.006)$ & $(0.005)$ & $(0.004)$ & $(0.004)$ \\
\hline \multirow[t]{2}{*}{ Right } & $0.027 * * *$ & $0.030 * * *$ & $0.027 * * *$ & $0.027 * * *$ \\
\hline & $(0.006)$ & $(0.006)$ & $(0.005)$ & $(0.005)$ \\
\hline \multicolumn{5}{|l|}{ Occupation Dummies } \\
\hline \multirow[t]{2}{*}{ Unemployed } & $-0.030 * * *$ & $-0.032 * * *$ & $-0.046 * * *$ & $-0.047 * * *$ \\
\hline & $(0.011)$ & $(0.010)$ & $(0.009)$ & $(0.007)$ \\
\hline \multirow[t]{2}{*}{ Retired } & 0.004 & -0.004 & $-0.015 * * *$ & $-0.011 * * *$ \\
\hline & $(0.007)$ & $(0.005)$ & $(0.005)$ & $(0.004)$ \\
\hline \multicolumn{5}{|c|}{ Economic Expectations (BL: Same) } \\
\hline \multirow[t]{2}{*}{ Better } & $0.016^{* * *}$ & $0.017 * * *$ & $0.030 * * *$ & $0.025 * * *$ \\
\hline & $(0.005)$ & $(0.005)$ & $(0.007)$ & $(0.007)$ \\
\hline \multirow[t]{2}{*}{ Worse } & $-0.041 * * *$ & $-0.041 * * *$ & $-0.027 * * *$ & $-0.032 * * *$ \\
\hline & $(0.006)$ & $(0.006)$ & $(0.009)$ & $(0.005)$ \\
\hline \multicolumn{5}{|l|}{ Income (BL: Q1) } \\
\hline \multirow[t]{2}{*}{ Q2 } & $0.029 * * *$ & & & \\
\hline & $(0.007)$ & & & \\
\hline \multirow[t]{2}{*}{ Q3 } & $0.036 * * *$ & & & \\
\hline & $(0.006)$ & & & \\
\hline \multirow[t]{2}{*}{ Q4 } & $0.061 * * *$ & & & \\
\hline & $(0.006)$ & & & \\
\hline \multicolumn{5}{|l|}{ Other Dummies } \\
\hline Trust in EU Commission & $0.385 * * *$ & $0.386 * * *$ & $0.418 * * *$ & $0.411 * * *$ \\
\hline
\end{tabular}

persistent intra-zone dispersion in inflation rates (see, e.g., Altissimo et al., 2011; Gregoriou et al., 2011). Yet, removing the statistically insignificant inflation terms does not change the essence of the reported results. 


\begin{tabular}{|l|c|c|c|c|}
\hline & $(0.010)$ & $(0.009)$ & $(0.003)$ & $(0.005)$ \\
\hline SGPDEF & $-0.059 * *$ & $-0.064 * *$ & -0.022 & $-0.046^{*}$ \\
\hline SGPDEBT & $(0.028)$ & $(0.028)$ & $(0.018)$ & $(0.025)$ \\
\hline & -0.015 & $-0.040 * *$ & $-0.064 * *$ & $-0.052^{* *}$ \\
\hline Hyperinflation & $(0.018)$ & $(0.018)$ & $(0.030)$ & $(0.023)$ \\
\hline & 0.028 & -0.020 & 0.021 & 0.035 \\
\hline EU6 & $(0.027)$ & $(0.018)$ & $(0.027)$ & $(0.024)$ \\
\hline & 0.010 & 0.011 & 0.013 & 0.018 \\
\hline EU12 & $(0.025)$ & $(0.025)$ & $(0.025)$ & $(0.024)$ \\
\hline & & 0.023 & -0.052 & -0.046 \\
\hline EU2004 & & $(0.035)$ & $(0.038)$ & $(0.038)$ \\
\hline & & $0.069 * * *$ & -0.015 & $-0.039 *$ \\
\hline & & $(0.027)$ & $(0.029)$ & $(0.022)$ \\
\hline Observations & & & & 205,575 \\
\hline Pseudo R-Square & 29,297 & 112,930 & 110,504 & 0.37 \\
\hline
\end{tabular}

Notes: See Table 3.

Comparing tables 3 and 4, it appears that our initial findings and interpretations have to be nuanced, as follows. Expected inflation (one year ahead from the year of the respective survey wave) now emerges as a key macroeconomic (country-level) determinant of trust in the ECB for the full sample period, 1999-2015. However, it only becomes significant in the later subperiod, with a relative importance that has increased over time: measured in terms of the estimated average marginal effect, it has risen from statistical insignificance in the pre-GFC (1999-2008) subsample to positive significance of a magnitude of 0.125 in the post-GFC (2008-2015) subsample and, hence, to 0.115 for the entire (1999-2015) sample. This magnitude nevertheless ranks the relative influence of expected inflation on the estimated trust in the ECB as the second largest among the included explanatory variables. It is roughly four times weaker than a positive general pro-EU attitude, as proxied by trust in the European Commission, and about twice stronger than the negative influence of macro-variables such as measures of fiscal problems, whose magnitude is also comparable to that of the strongest positively-influencing socio-demographic variable, namely, the highest range of acquired education $(20+)$.

Thus, the strongest determinant of trust in the ECB as captured by the average marginal effect in our estimated logit regressions in both tables 3 and 4 is a pro-EU attitude. Its contribution is significantly positive and of a magnitude of 0.397 (Table 3) to 0.411 (Table 4) for the whole sample (1999-2015). Interestingly, this factor has been dynamically stable, rising slightly from 0.386 for the pre-GFC subsample to 0.418 for the post-GFC subsample (estimates as in Table 4). With the second largest influence accounted by expected inflation, two other macroeconomic dummies come in third position in terms of their estimated (although 
negative) relative influence on trust in the ECB: the two measures of fiscal difficulties: the deficit-to-GDP and debt-to-GDP ratios with regard to the SGP ceilings (Table 4). Then, as reflected in Table 4, the unemployed micro-level dummy has evolved from a significant negative average marginal contribution of -0.032 in the pre-GFC subsample to -0.046 in the post-GFC subsample, resulting in a whole sample magnitude of -0.047. Similarly, the debt-toGDP macro-level dummy has increased its relative contribution from significant negative 0.040 in the pre-GFC subsample to -0.064 in the post-GFC subsample, with an overall magnitude of -0.052 in the whole sample. By contrast, the deficit-to-GDP macro-level dummy has lost some of its relative importance as trust determinant of the ECB, from significant -0.064 pre-GFC to insignificant post-GFC and finally significant -0.046 in the whole sample.

The relative importance among the socio-demographic determinants of trust in the ECB in Table 4 when compared with Table 3 is generally preserved, in statistical significance as well as in sign and magnitude of the estimated average marginal effects. High education continues to account for the strongest, and positive, influence: in absolute value of magnitude, the most educated fraction of the EMU population matters roughly as much as the negative influence of both the unemployed micro-level dummy and the fiscal macro-level determinants, but twice less than the positive influence of expected inflation. The marginal effect of high education $(20+)$ has been slightly declining, though, in a dynamic perspective: from 0.067 pre-GFC to 0.056 post-GFC and ultimately 0.052 for the whole sample (Table 4 ). The relative influence of the many other statistically significant socio-demographic determinants of trust in the ECB is roughly at least twice weaker than that of high education.

Table 4 thus confirms what Table 3 already uncovered: ECB is trusted more by the older people, but their post-GFC support has declined from the corresponding pre-GFC support, more so for the working population of 45-64 years of age (in Table 4, from 0.032 in the preGFC subsample to 0.021 in the post-GFC subsample and 0.016 for the whole sample). The same holds true for the political orientation, where the trust of the centre-oriented population layers has declined much more pre- (0.023) versus post- (0.009) GFC to account for 0.015 over the whole sample, relative to the right-oriented ones (displaying approximate dynamic stability of the estimated coefficients: 0.030 against 0.027 , by GFC sub-period, and 0.027 for the whole sample). Favourable expectations regarding the economic situation have also increased their positive relative influence on trust in the ECB from pre- (0.017) to post- 
(0.030) GFC, to arrive at 0.025 for the whole sample. At the same time, unfavourable expectations with respect to the economic situation have decreased their negative relative influence from pre- $(-0.041)$ to post- $(-0.027)$ GFC, to arrive at -0.032 for the whole sample. The retired people dummy has increased its relative influence as determinant of trust in the ECB from statistical insignificance pre-GFC to significant -0.015 post-GFC, to account in the whole sample for a significant -0.011 .

Another result worth noting is that the neither the founding EU6 nor the subsequent EMU12 subgroup dummies are ever significant, whereas the EU2004 newcomer subgroup dummy has first (in the sub-period 1999-2008) accorded higher trust to the ECB, before becoming more sceptical, as the coefficient is significant and equal to -0.039 for the whole sample (Table 4 ).

\subsection{Robustness Checks: Adding Interaction Terms}

As a key robustness check, we report next results with the introduction of interactions between the socio-demographic characteristics and expected or observed inflation. ${ }^{19}$ Table 5 adds interactions with expected inflation, and reveals a further refinement in the interpretation of our results reported in Table 4.

Table 5. Regression Results Using Interactions with Expected Inflation

\begin{tabular}{|c|c|c|c|c|}
\hline & $(1)$ & (2) & (3) & (4) \\
\hline & 1999-2004 & 1999-2008 & $2009-2015$ & 1999-2015 \\
\hline \multirow[t]{2}{*}{ Expected Inflation } & -0.043 & $-0.308 * *$ & -0.047 & -0.063 \\
\hline & $(0.048)$ & $(0.129)$ & $(0.043)$ & $(0.041)$ \\
\hline \multirow{2}{*}{ Gender Dummy (BL: Male) } & $-0.066 * * *$ & -0016 & -0013 & 0014 \\
\hline & $(0.023)$ & $(0.014)$ & $(0.017)$ & $(0.014)$ \\
\hline \multirow[t]{2}{*}{ Gender x Exp. Infl. } & $0.030 * *$ & -0.009 & -0.013 & -0.011 \\
\hline & $(0.015)$ & $(0.010)$ & $(0.009)$ & $(0.008)$ \\
\hline \multicolumn{5}{|l|}{ Age (BL: 15-24) } \\
\hline \multirow[t]{2}{*}{$25-44$} & -0.026 & -0.022 & $-0.063 * *$ & -0.032 \\
\hline & $(0.065)$ & $(0.042)$ & $(0.025)$ & $(0.023)$ \\
\hline \multirow[t]{2}{*}{$45-64$} & -0.077 & -0.046 & $-0.081 * * *$ & $-0.056 * *$ \\
\hline & $(0.072)$ & $(0.046)$ & $(0.028)$ & $(0.026)$ \\
\hline \multirow[t]{2}{*}{$65+$} & -0.055 & -0.075 & $-0.054 * *$ & -0.035 \\
\hline & $(0.066)$ & $(0.051)$ & $(0.026)$ & $(0.027)$ \\
\hline \multirow[t]{2}{*}{ (25-44) x Exp. Infl. } & 0.017 & 0.019 & $0.045 * * *$ & $0.024 *$ \\
\hline & $(0.040)$ & $(0.023)$ & $(0.016)$ & $(0.014)$ \\
\hline
\end{tabular}

\footnotetext{
${ }^{19}$ Of course, we conducted a much more exhaustive sensitivity analysis, including in EU - not just EMU subsamples; see the working paper, Farvaque et al. (2011).
} 


\begin{tabular}{|c|c|c|c|c|}
\hline \multirow[t]{2}{*}{ (45-64) x Exp. Infl. } & 0.056 & $0.044 *$ & $0.067 * * *$ & $0.049 * * *$ \\
\hline & $(0.041)$ & $(0.025)$ & $(0.018)$ & $(0.016)$ \\
\hline \multirow[t]{2}{*}{$(65+)$ x Exp. Infl. } & 0.043 & $0.063 * *$ & $0.064^{* * * *}$ & $0.045^{* * *}$ \\
\hline & $(0.039)$ & $(0.029)$ & $(0.016)$ & $(0.016)$ \\
\hline \multicolumn{5}{|l|}{ Education (BL: Up to 15$)$} \\
\hline \multirow[t]{2}{*}{$16-19$} & 0.020 & -0.043 & -0.020 & -0.030 \\
\hline & $(0.053)$ & $(0.034)$ & $(0.020)$ & $(0.020)$ \\
\hline \multirow[t]{2}{*}{$20+$} & $0.113 *$ & $-0.071 *$ & -0.032 & -0.024 \\
\hline & $(0.062)$ & $(0.040)$ & $(0.021)$ & $(0.021)$ \\
\hline \multirow[t]{2}{*}{ Still studying } & -0.067 & $-0.134 *$ & -0.062 & $-0.073 *$ \\
\hline & $(0.086)$ & $(0.074)$ & $(0.038)$ & $(0.039)$ \\
\hline \multirow[t]{2}{*}{ (16-19) x Exp. Infl. } & -0.009 & $0.039 * *$ & $0.028 * * *$ & $0.033 * * *$ \\
\hline & $(0.033)$ & $(0.019)$ & $(0.011)$ & $(0.011)$ \\
\hline \multirow[t]{2}{*}{$(20+)$ x Exp. Infl. } & -0.057 & $0.077 * * *$ & $0.061 * * *$ & $0.053 * * *$ \\
\hline & $(0.036)$ & $(0.022)$ & $(0.011)$ & $(0.010)$ \\
\hline \multirow[t]{2}{*}{ (Still Studying) x Exp. Infl. } & 0.041 & $0.097 * *$ & $0.056^{* *}$ & $0.062 * * *$ \\
\hline & $(0.052)$ & $(0.041)$ & $(0.022)$ & $(0.022)$ \\
\hline \multicolumn{5}{|l|}{ Political Placement (BL: Left) } \\
\hline \multirow[t]{2}{*}{ Centre } & -0.034 & 0.026 & 0.001 & 0.002 \\
\hline & $(0.047)$ & $(0.025)$ & $(0.013)$ & $(0.010)$ \\
\hline \multirow[t]{2}{*}{ Right } & 0.003 & 0.021 & 0.000 & 0.017 \\
\hline & $(0.061)$ & $(0.029)$ & $(0.020)$ & $(0.018)$ \\
\hline \multirow[t]{2}{*}{ Centre x Exp. Infl. } & 0.038 & -0.002 & 0.006 & 0.009 \\
\hline & $(0.028)$ & $(0.013)$ & $(0.010)$ & $(0.006)$ \\
\hline \multirow[t]{2}{*}{ Right x Exp. Infl. } & 0.016 & 0.005 & 0.018 & 0.007 \\
\hline & $(0.039)$ & $(0.017)$ & $(0.012)$ & $(0.010)$ \\
\hline \multicolumn{5}{|l|}{ Occupation Dummies } \\
\hline \multirow[t]{2}{*}{ Unemployed } & $-0.030 * * *$ & $-0.031 * * *$ & $-0.035^{* * *}$ & $-0.033 * * *$ \\
\hline & $(0.010)$ & $(0.010)$ & $(0.008)$ & $(0.007)$ \\
\hline \multirow[t]{2}{*}{ Retired } & 0.005 & -0.004 & $-0.012 * *$ & $-0.007 *$ \\
\hline & $(0.008)$ & $(0.005)$ & $(0.005)$ & $(0.004)$ \\
\hline \multicolumn{5}{|c|}{ Economic Expectations (BL: Same) } \\
\hline Better & $0.017 * * *$ & $0.018 * * *$ & $0.030 * * *$ & $0.027 * * *$ \\
\hline & $(0.005)$ & $(0.005)$ & $(0.006)$ & $(0.006)$ \\
\hline Worse & $-0.043 * * *$ & $-0.043 * * *$ & $-0.039 * * *$ & $-0.041 * * *$ \\
\hline & $(0.007)$ & $(0.006)$ & $(0.007)$ & $(0.005)$ \\
\hline Income (BL: Q1) & & & & \\
\hline Q2 & $0.028 * * *$ & & & \\
\hline & $(0.007)$ & & & \\
\hline Q3 & $0.035 * * *$ & & & \\
\hline & $(0.006)$ & & & \\
\hline Q4 & $0.060 * * *$ & & & \\
\hline & $(0.006)$ & & & \\
\hline Other dummies & & & & \\
\hline Trust in EU Commission & $0.385 * * *$ & $0.386 * * *$ & $0.404 * * *$ & $0.397 * * *$ \\
\hline & $(0.010)$ & $(0.009)$ & $(0.003)$ & $(0.005)$ \\
\hline SGPDEF & $-0.064 * *$ & $-0.067 * *$ & $-0.053 * *$ & $-0.061 * * *$ \\
\hline & $(0.025)$ & $(0.027)$ & $(0.020)$ & $(0.021)$ \\
\hline SGPDEBT & -0.013 & $-0.040 * *$ & $-0.049 *$ & $-0.041 * *$ \\
\hline & $(0.018)$ & $(0.018)$ & $(0.029)$ & $(0.020)$ \\
\hline Hyperinflation & 0.026 & -0.016 & 0.012 & 0.015 \\
\hline & $(0.027)$ & $(0.018)$ & $(0.021)$ & $(0.019)$ \\
\hline EU6 & 0.011 & 0.011 & 0.004 & 0.010 \\
\hline & $(0.025)$ & $(0.024)$ & $(0.019)$ & $(0.021)$ \\
\hline EU12 & & 0.019 & -0.048 & -0.028 \\
\hline & & $(0.036)$ & $(0.030)$ & $(0.031)$ \\
\hline EU2004 & & $0.065^{* *}$ & -0.001 & 0.011 \\
\hline
\end{tabular}




\begin{tabular}{|l|c|c|c|c|}
\hline & & $(0.029)$ & $(0.023)$ & $(0.021)$ \\
\hline & & & & \\
\hline Observations & 29,297 & 112,930 & 110,504 & 205,575 \\
\hline Pseudo R-Square & 0.31 & 0.33 & 0.41 & 0.38 \\
\hline
\end{tabular}

Notes: See Table 3.

Now the interaction terms with expected inflation have picked up all or most of the statistical significance of the corresponding socio-demographic variables kept as non-interacted regressors. Moreover, inflation expectations remain significant but now negative, with a relatively strong average marginal effect of -0.308 , although only pre-GFC. This indicates that before deflationary trends and fears emerged in the zero lower bound (ZLB) environment following the GFC what mattered to build up trust in the ECB were expectations of lower inflation, as it should naturally be more intuitive. With regard to the socio-demographic factors, political colour and also gender (except before the EU enlargement in 2004) lose statistical significance. The rest of the results are essentially unchanged, with the nuance that the interaction terms with inflation expectations display stronger marginal effects relative to the corresponding factors that are in the regression but not interacted. Otherwise, education, age, and income when interacted with inflation expectations remain of the same significance and sign and of a close magnitude to their estimated effects without these interactions reported in Table 4. The statistical significance and relative influence of optimistic expectations regarding the future of the economy and the dummies such as unemployed, retired, pro-EU attitude and fiscal prudence are also kept with the same significance levels and sign and no much quantitative change.

Finally, Table 6 adds interactions with actual inflation (in place of the interactions with expected inflation in Table 5), and can therefore be compared to Table 3.

Now, most importantly, actual inflation remains insignificant throughout, as was in Table 3. The nuance, however, analogous to what we stressed about Table 5, is that the interacted term of actual inflation with gender shows that men tended to accord more trust to the ECB than women before the EU enlargement in 2004 and, less so, before the GFC. Differently from Table 5, the interacted terms with actual inflation do not pick up the statistical significance of most of the influential socio-demographic characteristics as reported in tables 3 and 4 , and the signs are generally unchanged and with mostly similar magnitudes. 
Table 6. Regression Results Using Interactions with Actual Inflation

\begin{tabular}{|c|c|c|c|c|}
\hline & $(1)$ & $(2)$ & (3) & (4) \\
\hline & 1999-2004 & $1999-2008$ & $2009-2015$ & 1999-2015 \\
\hline \multirow[t]{2}{*}{ Inflation } & -0.006 & -0.013 & -0.005 & -0.006 \\
\hline & $(0.013)$ & $(0.010)$ & $(0.007)$ & $(0.007)$ \\
\hline \multirow[t]{2}{*}{ Gender Dummy (BL: Male) } & $-0.034 * * *$ & $-0.048 * * *$ & $-0.034 * * *$ & $-0.036 * * *$ \\
\hline & $(0.010)$ & $(0.011)$ & $(0.008)$ & $(0.007)$ \\
\hline \multirow[t]{2}{*}{ Gender $\mathrm{x}$ Inflation } & $0.008 * *$ & $0.007 *$ & 0.000 & 0.002 \\
\hline & $(0.004)$ & $(0.004)$ & $(0.001)$ & $(0.002)$ \\
\hline \multicolumn{5}{|l|}{$\operatorname{Age}(B L: 15-24)$} \\
\hline \multirow[t]{2}{*}{$25-44$} & -0.023 & 0.001 & 0.005 & 0.006 \\
\hline & $(0.018)$ & $(0.016)$ & $(0.005)$ & $(0.006)$ \\
\hline \multirow[t]{2}{*}{$45-64$} & $-0.027 *$ & 0.025 & $0.019 * * *$ & $0.020 * *$ \\
\hline & $(0.014)$ & $(0.023)$ & $(0.006)$ & $(0.008)$ \\
\hline \multirow[t]{2}{*}{$65+$} & -0.005 & 0.034 & $0.042 * * *$ & $0.037 * * *$ \\
\hline & $(0.018)$ & $(0.022)$ & $(0.010)$ & $(0.011)$ \\
\hline \multirow[t]{2}{*}{$(25-44) \times$ Inflation } & 0.010 & 0.004 & 0.004 & 0.001 \\
\hline & $(0.008)$ & $(0.006)$ & $(0.003)$ & $(0.003)$ \\
\hline \multirow[t]{2}{*}{ (45-64) x Inflation } & $0.017 * *$ & 0.003 & $0.005^{*}$ & 0.003 \\
\hline & $(0.007)$ & $(0.008)$ & $(0.003)$ & $(0.004)$ \\
\hline \multirow[t]{2}{*}{$(65+) \times$ Inflation } & 0.007 & 0.001 & 0.005 & 0.001 \\
\hline & $(0.011)$ & $(0.008)$ & $(0.004)$ & $(0.005)$ \\
\hline \multicolumn{5}{|l|}{ Education (BL: Up to 15$)$} \\
\hline \multirow[t]{2}{*}{$16-19$} & -0.005 & 0.018 & $0.024 * * *$ & $0.022 * * *$ \\
\hline & $(0.012)$ & $(0.012)$ & $(0.007)$ & $(0.007)$ \\
\hline \multirow[t]{2}{*}{$20+$} & $0.023 *$ & $0.062 * * *$ & $0.057 * * *$ & $0.058 * * *$ \\
\hline & $(0.013)$ & $(0.021)$ & $(0.014)$ & $(0.014)$ \\
\hline \multirow[t]{2}{*}{ Still studying } & -0.002 & $0.032 *$ & $0.021 *$ & $0.026 * *$ \\
\hline & $(0.025)$ & $(0.018)$ & $(0.011)$ & $(0.010)$ \\
\hline \multirow[t]{2}{*}{$(16-19) \times$ Inflation } & 0.006 & 0.003 & 0.001 & 0.003 \\
\hline & $(0.007)$ & $(0.005)$ & $(0.002)$ & $(0.002)$ \\
\hline \multirow[t]{2}{*}{$(20+) \times$ Inflation } & -0.000 & 0.001 & $0.006 * *$ & 0.003 \\
\hline & $(0.006)$ & $(0.007)$ & $(0.002)$ & $(0.003)$ \\
\hline \multirow[t]{2}{*}{ (Still Studying) $\mathrm{x}$ Inflation } & 0.001 & 0.002 & 0.005 & 0.002 \\
\hline & $(0.011)$ & $(0.006)$ & $(0.005)$ & $(0.004)$ \\
\hline \multicolumn{5}{|l|}{ Political Placement (BL: Left) } \\
\hline \multirow[t]{2}{*}{ Centre } & $0.020 *$ & 0.013 & $0.010 * *$ & $0.010^{*}$ \\
\hline & $(0.011)$ & $(0.013)$ & $(0.005)$ & $(0.005)$ \\
\hline \multirow[t]{2}{*}{ Right } & 0.012 & 0.016 & $0.025 * * *$ & $0.024 * * *$ \\
\hline & $(0.014)$ & $(0.013)$ & $(0.006)$ & $(0.006)$ \\
\hline Centre x Inflation & 0.002 & 0.004 & 0.002 & $0.004 * * *$ \\
\hline & $(0.004)$ & $(0.005)$ & $(0.001)$ & $(0.002)$ \\
\hline Right $x$ Inflation & 0.007 & 0.006 & 0.003 & 0.003 \\
\hline & $(0.008)$ & $(0.004)$ & $(0.002)$ & $(0.002)$ \\
\hline Occupation Dummies & & & & \\
\hline Unemployed & $-0.026 * *$ & $-0.032 * * *$ & $-0.035 * * *$ & $-0.033 * * *$ \\
\hline & $(0.010)$ & $(0.009)$ & $(0.008)$ & $(0.007)$ \\
\hline Retired & 0.009 & -0.004 & $-0.012 * *$ & $-0.007 *$ \\
\hline & $(0.006)$ & $(0.004)$ & $(0.005)$ & $(0.004)$ \\
\hline Economic Expectations (BL & & & & \\
\hline Better & $0.016 * * *$ & $0.018 * * *$ & $0.030 * * *$ & $0.027 * * *$ \\
\hline & $(0.005)$ & $(0.006)$ & $(0.006)$ & $(0.006)$ \\
\hline Worse & $-0.044 * * *$ & $-0.043 * * *$ & $-0.039 * * *$ & $-0.041 * * *$ \\
\hline & $(0.007)$ & $(0.006)$ & $(0.008)$ & $(0.005)$ \\
\hline
\end{tabular}




\begin{tabular}{|c|c|c|c|c|}
\hline \multicolumn{5}{|l|}{ Income (BL: Q1) } \\
\hline \multirow[t]{2}{*}{ Q2 } & $0.028 * * *$ & & & \\
\hline & $(0.007)$ & & & \\
\hline \multirow[t]{2}{*}{ Q3 } & $0.036 * * *$ & & & \\
\hline & $(0.007)$ & & & \\
\hline \multirow[t]{2}{*}{ Q4 } & $0.062 * * *$ & & & \\
\hline & $(0.006)$ & & & \\
\hline \multicolumn{5}{|l|}{ Other Dummies } \\
\hline \multirow[t]{2}{*}{ Trust in EU Commission } & $0.383 * * *$ & $0.386 * * *$ & $0.404 * * *$ & $0.397 * * *$ \\
\hline & $(0.010)$ & $(0.008)$ & $(0.003)$ & $(0.005)$ \\
\hline \multirow[t]{2}{*}{ SGPDEF } & $-0.068 * * *$ & $-0.066^{* *}$ & $-0.053 * *$ & $-0.061 * * *$ \\
\hline & $(0.024)$ & $(0.029)$ & $(0.021)$ & $(0.021)$ \\
\hline \multirow[t]{2}{*}{ SGPDEBT } & -0.021 & $-0.039 * *$ & $-0.048 *$ & $-0.041 * *$ \\
\hline & $(0.014)$ & $(0.018)$ & $(0.028)$ & $(0.020)$ \\
\hline \multirow[t]{2}{*}{ Hyperinflation } & 0.034 & -0.011 & 0.010 & 0.015 \\
\hline & $(0.029)$ & $(0.019)$ & $(0.021)$ & $(0.019)$ \\
\hline \multirow[t]{2}{*}{ EU6 } & 0.017 & 0.010 & 0.005 & 0.010 \\
\hline & $(0.021)$ & $(0.023)$ & $(0.019)$ & $(0.020)$ \\
\hline \multirow[t]{2}{*}{ EU12 } & & 0.014 & -0.046 & -0.027 \\
\hline & & $(0.038)$ & $(0.031)$ & $(0.032)$ \\
\hline \multirow[t]{2}{*}{ EU2004 } & & $0.064 * *$ & -0.001 & 0.011 \\
\hline & & $(0.029)$ & $(0.023)$ & $(0.021)$ \\
\hline Observations & 29,297 & 112,930 & 110,504 & 205,575 \\
\hline Pseudo R-Square & 0.31 & 0.33 & 0.41 & 0.38 \\
\hline
\end{tabular}

Notes: See Table 3.

A natural interpretation of these results is that, in 'normal times' (i.e., when macroeconomic prospects induce a positive inflation rate - potentially higher than the targeted one), as was the case for the EMU before the GFC, expected inflation has a strong negative influence (significant average marginal effect of -0.308 over 1999-2008 in Table 5) on trust in the ECB. By contrast, in the exceptional situation of 'deflation scares' (when fighting deflation is of prime concern), as was the ECB case operating at the ZLB after the GFC, expected inflation has an apparently counterintuitive - but, as we argue here, still logical - weaker positive influence (significant average marginal effect of 0.125 over 2009-2015 in Table 4) on trust in the ECB. 


\section{Conclusions}

All in all, then, our results confirm the importance and stability of socio-demographic determinants of trust in the ECB. Concerning the macro-level determinants, our findings reveal that expected rather than actual inflation matters, and with a relative influence that depends upon the macroeconomic environment (pre- versus post-GFC, in particular). Moreover, another novel result is that the sign (not just the magnitude) of the estimated average marginal effect of expected inflation changes across time and country composition of the EMU sample, uncovering an insightful dynamic relationship.

Beyond, and in addition to, country-level inflation perceptions in a given macroeconomic context, we looked into many micro-factors and asked: "Who supports the ECB?" Our empirical findings provide these answers: people with higher - rather than lower - level of education; people with higher - rather than lower - level of income; people with centre to right-wing - rather than left-wing - political orientation; people with optimistic expectations on the economic situation; men - rather than women. Not surprisingly, the unemployed are among the socio-demographic groups that trust the ECB less, as they would care primarily to find a job, and so a source of income.

Hence, our results suggest that the level of support for the ECB is quite predictably determined by a number of time-invariant individual characteristics, or at least by ones that are only likely to move very slowly. Trust in the ECB is also determined by expected (and not actual) inflation. The key macro-policy implication, then, is that the ECB should be able to deliver inflation close to its target (around $2 \%$ per year, on average) to anchor inflation expectations as a key macro-determinant of trust in the ECB. In turn, the key communicationstrategy implication appears to be that, being unable to modify the micro-determinants, the ECB should at least adapt its communication with due respect to their nuances we revealed. It has to channel its central bank 'speak' to the various different categories of citizens, depending upon their estimated degree of support. It is nowadays widely recognized that if a central bank is to exert some influence on the economy, such an influence depends critically 
on its ability to manage market, and thus agents', expectations. ${ }^{20}$ Communication being a fundamental aspect of this ability, knowing with whom to communicate is of key importance, especially for a supranational institution such as the ECB, as the distance to the citizens is larger than for national central banks.

${ }^{20}$ This issue is of course related to the degree of (economic and financial) literacy of the audience, and goes beyond the European case (see Carvalho and Nechio, 2014, for a related analysis for the US). 


\section{References}

Akerlof, G., Dickens, W. and Perry, G. (1996) “The Macroeconomics of Low Inflation”. Brookings Papers on Economic Activity, Vol. 27, No. 1, pp. 1-76.

Altissimo, F., Benigno, P. and Palenzuela, D.R. (2011) "Inflation Differentials in a Currency Area: Facts, Explanation and Policy”. Open Economies Review, Vol. 22, No. 2, pp. 189-233.

Banducci, S.A., Karp, J.A. and Loedel, P.H. (2009) "Economic Interests and Public Support for the Euro". Journal of European Public Policy, Vol. 16, No. 4, pp. 564-581.

Berman, S. and McNamara, K. (1999) "Bank on Democracy”. Foreign Affairs, Vol. 78, No. 2, pp. 2-8.

Blinder, A.S., Ehrmann, M., Fratzscher, M., De Haan, J. and Jansen, D.-J. (2008) "Central Bank Communication and Monetary Policy: A Survey of Theory and Evidence". Journal of Economic Literature, Vol. 46, No. 4, pp. 910-945.

Buiter, W.H. (1999) "Alice in Euroland”. Journal of Common Market Studies, Vol. 37, No. 2, pp. 181-209.

Carvalho, C. and Nechio, F. (2014) "Do People Understand Monetary Policy?" Journal of Monetary Economics, Vol. 66 (September), pp. 108-123.

DuMouchel, W. H. and Duncan, G. J. (1983) "Using Sample Survey Weights in Multiple Regression Analyses of Stratified Samples". Journal of the American Statistical Association, Vol. 78, No. 383, pp. 535-543.

Ehrmann, M. and Fratzscher, M. (2007) "The Timing of Central Bank Communication". European Journal of Political Economy, Vol. 23, No. 1, pp. 124-145.

Ehrmann, M., Soudan, M. and Stracca, L. (2013) "Trust in the ECB in Normal and Crisis Times". Scandinavian Journal of Economics 115, No. 3, pp. 781-807.

Ehrmann, M. and Tzamourani, P. (2012) "Memories of High Inflation”. European Journal of Political Economy, Vol. 28, No. 2, pp. 174-191.

Farvaque, E., Héricourt, J. and Lagadec, G. (2010) "Central Bank Independence and Age- ing". Applied Economics Letters, Vol. 17, No. 12, pp. 1167-1171.

Farvaque, E. and Mihailov, A. (2009) "Intergenerational Transmission of Inflation Aversion: Theory and Evidence”. IRISS Working Paper No. 2009-11, CEPS/INSTEAD, Luxembourg.

Farvaque, E., Hayat, M. A. and Mihailov, A. (2011) "Who Supports the ECB? Evidence from Eurobarometer Survey Data”. Economics \& Management Discussion Paper 2011-04 (revised: May 2015), Henley Business School, Reading University. 
Fischer, J.V. and Hahn, V. (2008) "Determinants of Trust in the European Central Bank". Working Paper in Economics and Finance No. 695, Stockholm School of Economics.

Fischer, S., Sahay, R. and Vegh, C. (2002) "Modern Hyper- and High Inflations". Journal of Economic Literature, Vol. 40, No. 3, pp. 837-880.

Gabel, M. (1998) "Public Support for European Integration: An Empirical Test of Five Theories". Journal of Politics, Vol. 60, No. 2, pp. 333-354.

Gärtner, M. (1997) 'Who Wants the Euro -and Why? Economic Explanations of Public Attitudes towards a Single European Currency”. Public Choice, Vol. 93, No. 3, pp. 487-510.

Gregoriou, A., Kontonikas, A. and Montagnoli, A. (2011) "Euro Area Inflation Differentials: Unit Roots and Nonlinear Adjustment”. Journal of Common Market Studies, Vol. 49, No. 3, pp. 525-540.

Gros, D. and Roth, F. (2014) "Crisis and Citizens' Trust in the European Central Bank - Panel Data Evidence for the Euro Area, 1999-2012”. Journal of European Integration, Vol. 36, No. 3, 303-320.

Hainmüller, J. and Hiscox, M. (2006) "Learning to Love Globalization: Education and Individual Attitudes toward International Trade”. International Organization, Vol. 60, No. 2, pp. 469-498.

Hayo, B. (1999) "Knowledge and Attitude towards European Monetary Union". Journal of Policy Modeling, Vol. 21, No. 5, pp. 641-651.

Heckman, J.J. (1976) "The Common Structure of Statistical Models of Truncation, Sample Selection and Limited Dependent Variables and a Simple Estimator for Such Models". Annals of Economic and Social Measurement, Vol. 5, No. 4, pp. 475-492.

Heckman, J.J. (1979) "Sample Selection Bias as a Specification Error". Econometrica, Vol. 47, No. 1, pp. 153-161.

Hudson, J. (2006) "Institutional Trust and Subjective Well-Being across the EU". Kyklos, Vol. 59, No. 1, pp. 43-62.

Issing, O. (1999) "The Eurosystem: Transparent and Accountable or "Willem in Euroland"”. Journal of Common Market Studies, Vol. 37, No. 3, pp. 503-519.

Jayadev, A. (2006) "Differing Preferences between Anti-inflation and Anti-unemployment Policy among the Rich and the Poor". Economics Letters, Vol. 91, No. 1, pp. 67-71.

Jonung, L. (2004) "The Political Economy of Monetary Unification: The Swedish Euro Referendum of 2003”. Cato Journal, Vol. 24, pp. 123-150.

Kaltenthaler, K.C., and Anderson, C.J. (2001) "Europeans and Their Money: Explaining Public Support for the Common European Currency". European Journal of Political Research, Vol. 40, No. 2, pp. 139-170.

Kaltenthaler, K.C., Anderson, C. J. and Miller, W.J. (2010) "Accountability and Independent Central Banks: Europeans and Distrust of the European Central Bank". Journal of Common Market Studies, 
Vol. 48, No. 5, pp. 1261-1281.

Maier, P. and Bezoen, S. (2004) "Bashing and Supporting Central Banks: The Bundesbank and the European Central Bank". European Journal of Political Economy, Vol. 20, No. 4, pp. 923-939.

Maier, P. and Knaap, T. (2002) "Who Supported the Deutsche Bundesbank? An Empirical Investigation”. Journal of Policy Modeling, Vol. 24, No. 9, pp. 831-851.

Maier, P., Sturm, J.E., and De Haan, J. (2002) "Political Pressure on the Bundesbank: An Empirical Investigation Using the Havrilesky Approach". Journal of Macroeconomics, Vol. 24, No. 1, pp. 103123.

Malmendier, U. and Nagel, S. (2015) "Learning from Inflation Experiences". Quarterly Journal of Economics. Forthcoming: doi: 10.1093/qje/qjv037

McFadden, D. (1974) “The Measurement of Urban Travel Demand”. Journal of Public Economics, Vol. 3, pp. 303-328.

Moulton, B.R. (1990) "An Illustration of a Pitfall in Estimating the Effects of Aggregate Variables on Micro Units". Review of Economics and Statistics, Vol. 72, No. 2, pp. 334-338.

Nelsen, B.F. and Guth, J. (2000) "Exploring the Gender Gap: Women, Men and Public Attitudes toward European Integration”. European Union Politics, Vol. 1, No. 3, pp. 267- 291.

Roth, F. (2009) "The Effect of the Financial Crisis on Systemic Trust". Intereconomics: Review of European Economic Policy, Vol. 44, No. 4, pp. 203-208.

Rubin, D.B. (1987) Multiple Imputation for Nonresponse in Surveys. New York: Wiley.

Scheve, K. (2004) "Public Inflation Aversion and the Political Economy of Macroeconomic Policymaking”. International Organization, Vol. 58, No. 1, pp. 1-34.

Stevenson, B. and Wolfers, J. (2011) "Trust in Public Institutions over the Business Cycle". American Economic Review, Vol. 101, No. 3, pp. 281-287.

Waller, C.J. (1991), "Bashing and Coercion in Monetary Policy”. Economic Inquiry, 29 (1), pp. 1-13.

Walstad, W.B. and Rebeck, K. (2002) "Assessing the Economic Knowledge and Economic Opinions of Adults”. Quarterly Review of Economics and Finance, Vol. 42, No. 5, pp. 921-935.

Wälti, S. (2012) "Trust No More? The Impact of the Crisis on Citizens'Trust in Central Banks". Journal of International Money and Finance, Vol. 31, No. 3, pp. 593-605. 